\title{
THE EFFECT OF GENERAL ANAESTHESIA ON THE TOLERANCE OF CEREBRAL ISCHAEMIA IN RABBITS*
}

\author{
J. A. BaIN, M.D., D. V. CatTon, M.D., F.R.C.P.(C), J. M. R. CoX, M.D., \\ AND W. E. SPOEREL, M.D., F.R.C.P. (c) $\uparrow$
}

IN 1961 Drruva et al. ${ }^{1}$ reported that halothane anaesthesia could increase the tolerance of the brain to anoxia. Clinical and experimental studies by Keats and his group ${ }^{2,3}$ indicated that a certain protection against oxygen lack could be afforded by moderately deep general anaesthesia with cyclopropane or barbiturates. However, some of their studies lacked precise temperature control; Hirsch et al. ${ }^{4}$ demonstrated that even a slight reduction in body temperature improved survival. In our laboratory, Cox and co-workers ${ }^{b}$ found in rabbits a significant increase in survival after three and six minutes of cerebral ischaemia, when 1.5 per cent halothane was added to a nitrous oxide oxygen anaesthesia. The present report represents an expansion of this work, including other anaesthetic agents and a longer duration of ischaemia.

The method of applying a pneumatic tourniquet around the rabbit's neck was chosen to produce isolated cerebral ischaemia. Stewart and co-workers in $1906^{7}$ showed that occlusion of the carotid and vertebral arteries in the neck would produce complete cerebral ischaemia in the rabbit, but not in dogs or cats. German investigators, especially $\mathrm{Opitz}^{8}$ and Hirsch and their co-workers ${ }^{4,6}$ demonstrated the high degree of reproducibility of this technique. In comparison with other methods it has the advantage of simplicity, does not require any surgery, and is therefore highly suitable for survival studies.

\section{METHOD}

Anaesthesia was induced in all rabbits with 4 per cent halothane, nitrous oxide, and oxygen, using an anaesthetic chamber. Following orotracheal intubation with a stiff plastic tube, the animals were ventilated with the selected anaesthetic mixture for $\mathbf{4 5}$ minutes (induction and maintenance period, Table I). A Harvard animal respirator was used and the inflation pressure adjusted to about $15 \mathrm{~cm}$. $\mathrm{H}_{2} \mathrm{O}$ with a rate of $25 / \mathrm{min}$. An intravenous infusion containing 0.1 per cent succinylcholine was given to a maximum dose of $30 \mathrm{mg}$. to all animals during this period. An artery was cannulated for blood sampling and the recording of blood pressure; E.C.G. and bitemporal E.E.G. electrodes were attached. The rectal temperature was recorded at frequent intervals throughout the experiment and kept above $38.5^{\circ} \mathrm{C}$. by heating of the table surface.

'Presented at the Annual Meeting of the Canadian Anaesthetists' Society in Banff, Alberta, June 1966.

†Department of Anaesthesia and Department of Physiology, University of Western Ontario, London, Ontario. Dr. Bain held a fellowship of the Medical Research Council in 1965; Dr. Cox was an M.R.C. Fellow in 1963-64. 
TABLE I

EXPERIMENTAL Method
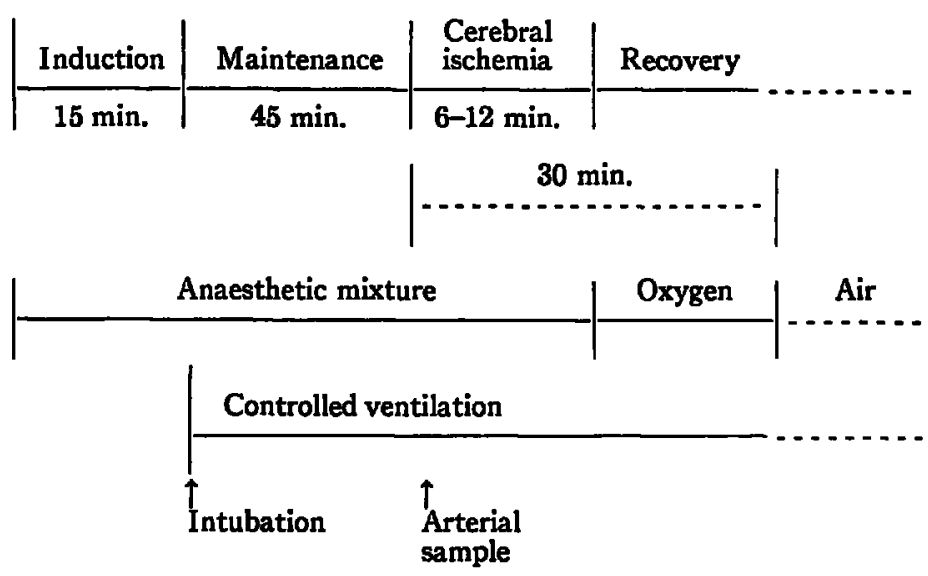

A pneumatic cuff, $5 \mathrm{~cm}$. in width, was tightly applied around the rabbit's neck and suddenly inflated from a pressure source to $700 \mathrm{~mm}$. Hg at the end of the maintenance period. Disappearance of all cortical impulses within about 30 seconds, and an isoelectric E.E.G. throughout the period the cuff was inflated, were considered evidence of a successful occlusion of cerebral blood flow. Cerebral ischaemia was maintained in this manner for three, six, nine, ten, and twelve minutes.

The anaesthetic mixture was replaced by oxygen one minute before the release of the occlusion. Artificial ventilation was continued with oxygen to the thirtieth minute from the beginning of occlusion and then with air until the animal was able to maintain its airway and an adequate respiration, as judged by the absence of cardiac slowing during a period of five minutes after the respirator had been detached.

After the recovery of an active cough reflex the rabbits were extubated and returned to their cages. $A$ coarse assessment of the neurological state was made at that time and 24 hours after the ischaemia. Animals alive after 24 hours were considered survivors.

All anaesthetic mixtures (Table II) were administered from a gas machine, using water depression flow meters and calibrated vaporizers (Fluotec or Pentec), with the exception of ether. In addition, the same agents in the same concentrations were used with oxygen alone. On the basis of their anaesthetic potency we

TABLE II

\begin{tabular}{|c|c|}
\hline Term used & Anaesthesia \\
\hline $\begin{array}{l}\text { No anaesthesia } \\
\mathrm{N}_{2} \mathrm{O} \text { (nitrous oxide) } \\
\mathrm{N}_{2} \mathrm{O} \text {-halothane } \\
\mathrm{N}_{2} \mathrm{O}, \mathrm{C}_{3} \mathrm{H}_{6} \\
\mathrm{~N}_{3} \mathrm{O} \text {-methoxyflurane } \\
\mathrm{N}_{2} \mathrm{O} \text {-ether }\end{array}$ & $\begin{array}{l}\text { Air + succinylcholine }(\mathrm{ScCh}) \\
\mathrm{N}_{2} \mathrm{O} 3 \mathrm{~L} .+\mathrm{O}_{2} 1 \mathrm{~L} .+\mathrm{ScCH} \\
\mathrm{N}_{2} \mathrm{O} 3 \mathrm{~L} .+\mathrm{O}_{2} 1 \mathrm{~L} \text {. + halothane } 1.5 \%+\mathrm{ScCh} \\
\mathrm{N}_{2} \mathrm{O}_{2} \mathrm{~L} .+\mathrm{O}_{2} 1 \mathrm{~L} \text {. + cyclopropane } 0.4 \mathrm{~L}+\mathrm{ScCh} \\
\mathrm{N}_{2} \mathrm{O}_{3} \mathrm{~L} \text {. }+\mathrm{O}_{2} 1 \mathrm{~L} \text {. + methoxyflurane } 0.8 \%+\mathrm{ScCh} \\
\mathrm{N}_{2} \mathrm{O}_{2} \mathrm{~L} \text { L. }+\mathrm{O}_{2} 1 \mathrm{~L} \text {. + diethyl ether } 5-10 \% \text { (estimated) + ScCh }\end{array}$ \\
\hline
\end{tabular}


will refer to halothane, methoxyflurane, cyclopropane, and diethyl ether as potent agents and to nitrous oxide as a weak anaesthetic agent.

The average weight of the rabbits was $7 \mathrm{lb}$.; rectal temperature, $\mathrm{pH}$ and $\mathrm{P}_{\mathrm{CO}_{2}}$, taken at the time of occlusion, were not different for survivors and non-survivors (Table III). The arterial oxygen tension was slightly above normal when nitrous oxide anaesthesia was used and markedly elevated when potent agents were given with oxygen only. The sex of the animals did not influence survival.

TABLE IIJ

Blood Gases, pH, Temperature, and Body Weight in SURVIVORS AND NON-SURVIVORS ( \pm S.E.M.)

\begin{tabular}{lcr}
\hline \hline & Survivors & Non-survivors \\
\hline $\mathrm{pH}$ & $7.40 \pm 0.01$ & $7.40 \pm 0.01$ \\
$\mathrm{Pco}_{2}$ (mm.Hg.) & $33.2 \pm 1.85$ & $32.3 \pm \mathbf{1 . 8 3}$ \\
$\mathrm{N}_{2} \mathrm{O}^{*}$ & $138.5 \pm 34$ & $149.6 \pm 48$ \\
$\mathrm{O}_{2}^{*}$ & $298.9 \pm 68$ & $\mathbf{3 5 9 . 6} \pm \mathbf{2 1}$ \\
Temp. $\left({ }^{\circ} \mathrm{C}\right.$ ) & $39.7 \pm 0.13$ & $39.9 \pm 0.17$ \\
Weight $(\mathrm{lb})$. & $7.0 \pm 0.20$ & $7.0 \pm 0.19$ \\
\hline *Blood gases determined immediately before cerebral \\
ischaemia (Table I).
\end{tabular}

In view of the discrepancy between anaesthesia with nitrous oxide and that with potent agents, we felt justified in investigating the effect of ischaemia on a small group of unanaesthetized rabbits. Here intubation with the help of succinylcholine was followed immediately, after application of the cuff and electrodes, by occlusion of cerebral blood flow; the post-ischaemic period was identical to that of the anaesthetized animals.

\section{Results}

A composite graph (Fig. 1) shows the events associated with cerebral ischaemia. $\mathbf{A}$ few seconds after the inflation there was a marked rise in systolic and diastolic pressure followed by cardiac irregularities and a considerable bradycardia. About this time, the electrocortical activity had been reduced to a few slow waves of very low amplitude and it became completely isoelectric a few seconds later.

After one to two minutes of continued ischaemia the heart regained its normal rate and irregularities disappeared; the blood pressure gradually fell to hypotensive levels during the course of occlusion. Release of the cuff was followed by a further slow fall in blood pressure with a gradual return to normotensive levels during the next five minutes. Cortical activity, reflexes, and respiratory activity returned later, their recovery time being proportional to the duration of cerebral ischaemia. A more detailed study of this response and its modification by various anaesthetic agents will be the subject of another publication.

The 24-hour survival of rabbits anaesthetized with anaesthetic mixtures containing nitrous oxide which were subjected to cerebral ischaemia for three, six, and nine minutes is listed in Table IV. Following three minutes of ischaemia, the survival of animals anaesthetized with halothane was significantly better; after a 


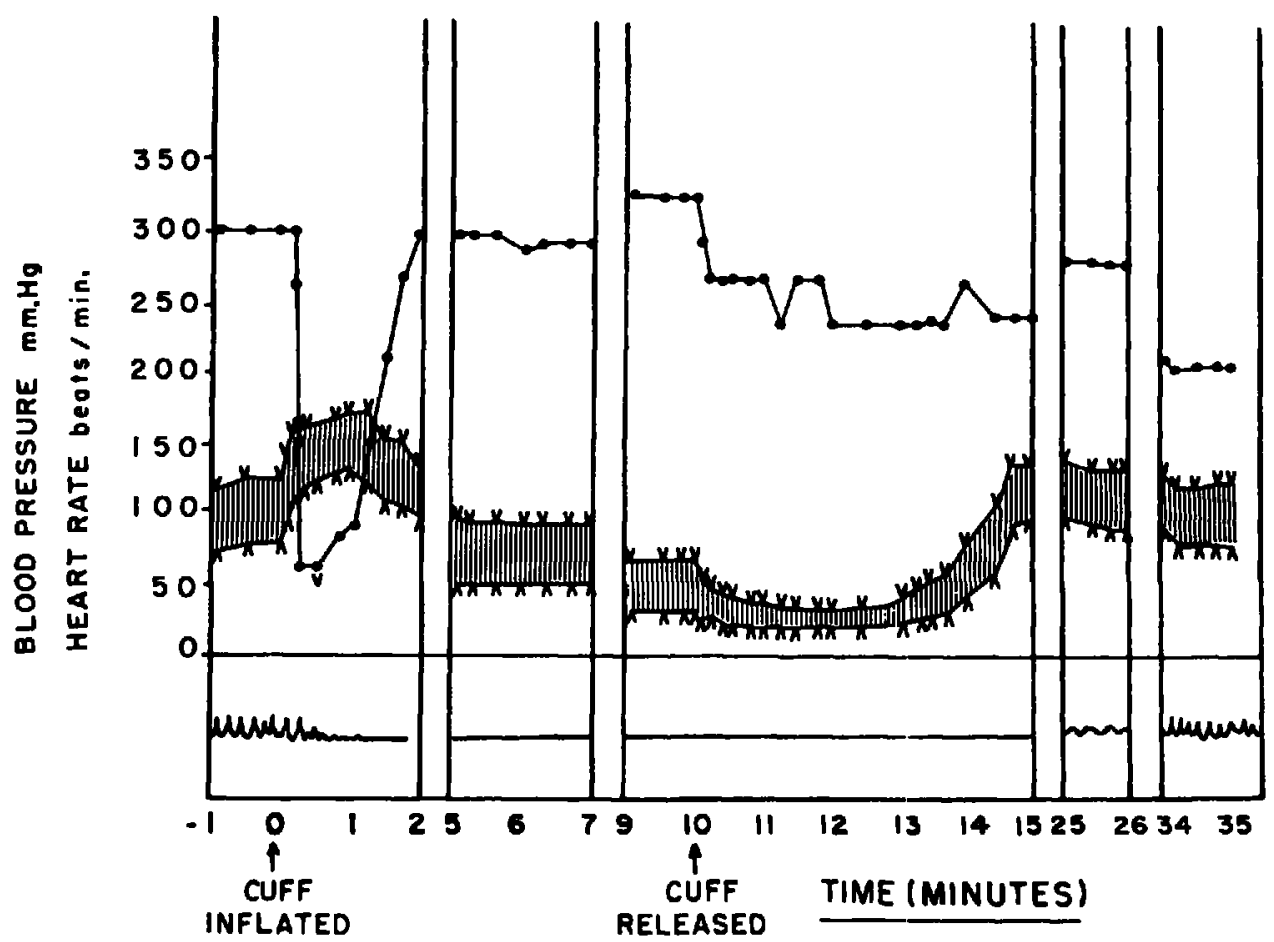

Ficure 1. Circulatory changes and E.E.G. response with arrest of cerebral blood flow by inflation of a cuff around the rabbit's neck. Graph from top to bottom: heart rate, blood pressure systolic and diastolic, and E.E.G.

six minute occlusion, rabbits anaesthetized with potent anaesthetic agents had a significantly better survival than unanaesthetized rabbits or those anaesthetized with nitrous oxide only. After nine minutes without cerebral blood flow, the survival was slightly, but not significantly, lower than in the six minute group.

The twenty-four hour survival appeared slightly better when the nitrous oxide

TABLE IV

Survival after 3, 6, and 9 Minutes of Cerebral Ischaemia without Anaesteesia aND With Nitrous OXIDE ANaEsThesta with OR Without SUPPLEMENTation by Potent Anaesthetic Agents (Table Ji)

\begin{tabular}{lcccr}
\hline \hline Anaesthesia & $\begin{array}{c}\text { Duration of } \\
\text { occlusion }\end{array}$ & $\begin{array}{c}\text { Number of } \\
\text { animals }\end{array}$ & $\begin{array}{c}\text { Number of } \\
\text { survivors } \\
\text { at 24 hours }\end{array}$ & $\%$ \\
\hline None & 3 & 3 & 3 & 100 \\
Nitrous oxide & 3 & 28 & 10 & 36 \\
Halothane & 3 & 19 & 18 & 95 \\
None & 6 & 6 & 1 & 17 \\
Nitrous oxide & 6 & 14 & 2 & 14 \\
Halothane & 6 & 6 & 6 & 100 \\
Methoxyflurane & 6 & 6 & 3 & 50 \\
Cyclopropane & 6 & 6 & 4 & 67 \\
Halothane & 9 & 10 & 4 & 40 \\
Methoxyflurane & 9 & 10 & 7 & $\mathbf{6 0}$ \\
Cyclopropane & 9 & 10 & 5 & $\mathbf{5 0}$ \\
Ether & 9 & & &
\end{tabular}


in the anaesthetic mixture was replaced by oxygen, leaving the concentration of the potent anaesthetic agent unchanged. A level of statistical significance was not reached with the number of experiments (Table V). Further prolongation of the cerebral ischaemia to ten and twelve minutes apparently did not decrease the survival. However, even a crude neurological assessment of the rabbit's condition at 24 hours indicated a marked increase in the severity of cerebral damage between nine and twelve minutes (Table VI).

\section{TABLE $V$}

Survival after 9, 10, and 12 Minutes of Cerebral Ischaemia with Potent ANaesthetic Agents (Concentrations as IN TABle II) AND OXYGEN

\begin{tabular}{lcccc}
\hline $\begin{array}{l}\text { Potent anaesthetic } \\
\text { agents with oxygen } \\
\text { alone }\end{array}$ & $\begin{array}{c}\text { Duration of } \\
\text { ischaemia }\end{array}$ & $\begin{array}{c}\text { Number of } \\
\text { animals }\end{array}$ & $\begin{array}{c}\text { Survivors } \\
\text { (24 hours) }\end{array}$ & $\%$ \\
\hline Halothane & 9 & 10 & 6 & 60 \\
Methoxyflurane & 9 & 10 & 8 & 80 \\
Cyclopropane & 9 & 10 & 6 & 60 \\
Ether & 9 & 10 & 7 & 70 \\
Halothane & 10 & 6 & 5 & $\mathbf{8 3}$ \\
Methoxyflurane & 10 & 6 & 4 & 67 \\
Cyclopropane & 10 & 6 & 1 & 17 \\
Ether & 10 & 6 & 3 & 50 \\
Halothane & 12 & 6 & 4 & 67 \\
Methoxyflurane & 12 & &
\end{tabular}

TABLE VI

Neurological Defects at 24 Hours after Cerebral ischaemia (\%)

\begin{tabular}{cccc}
\hline $\begin{array}{c}\text { Assessment of neurological } \\
\text { defect at 24 hours } \\
\text { (see code) }\end{array}$ & $\begin{array}{c}\text { 9 Minutes' } \\
\text { ischaemia } \\
\text { (40 animals) }\end{array}$ & $\begin{array}{c}\text { 10 Minutes' } \\
\text { ischaemia } \\
\text { (24 animals) }\end{array}$ & $\begin{array}{c}\text { 12 Minutes' } \\
\text { ischaemia } \\
\text { (12 animals) }\end{array}$ \\
\hline 0 & 2 & 0 & 0 \\
1 & 11 & 9 & 0 \\
2 & 24 & 26 & 13 \\
3 & 22 & 22 & 44 \\
Dead & 41 & 43 & 44 \\
\hline
\end{tabular}

CODE: Twenty-four hours after cerebral ischaemia the animals were classified as follows:

$0=$ no grossly detectable defects.

1 = severe ataxia but able to move about.

$\mathbf{2}=$ position reflexes partially recovered, i.e., holding up head, trying to sit up.

$3=$ position reflexes absent or poor.

Six animals were subjected to 3 per cent halothane-nitrous-oxide-oxygen anaesthesia and cerebral ischaemia of six and nine minutes' duration. These animals were severely hypotensive (often below $30 \mathrm{~mm} . \mathrm{Hg}$ ), yet the survival of four out of six following six minutes of ischaemia and of three out of six following nine minutes of ischaemia is in keeping with the results in the groups receiving standard anaesthetic concentrations. The blood pressure at the time when the tourniquet was released did not influence survival (Table VII). Anaesthesia with halothane and also with methoxyflurane caused a considerable hypotension but was associated with a better survival. 
TABLE VII

Systolic Blood Pressure at the Time of Release of Tourniquet after 3 and 6 Minutes of Cerebral Ischatmia

\begin{tabular}{|c|c|c|}
\hline & Number of Rabbits & $\begin{array}{c}\text { B.P. at cuff } \\
\text { release (mm. } \mathrm{Hg} \pm \text { S.E.M. }\end{array}$ \\
\hline \multicolumn{3}{|c|}{ THREE MINUTES' ISCHAEMIA } \\
\hline $\begin{array}{l}\text { Survivors }\left(\mathrm{N}_{2} \mathrm{O}\right) \\
\text { Survivors (halothane) } \\
\text { Non-Survivors }\left(\mathrm{N}_{2} \mathrm{O}\right)\end{array}$ & $\begin{array}{r}9 \\
18 \\
17\end{array}$ & $\begin{array}{r}136 \pm 12 \\
85 \pm 5 \\
97 \pm 10\end{array}$ \\
\hline \multicolumn{3}{|c|}{ SIX MINUTES' ISCHAEMIA } \\
\hline $\begin{array}{l}\text { Survivors (halothane) } \\
\text { Non-Survivors }\left(\mathrm{N}_{2} \mathrm{O}\right)\end{array}$ & $\begin{array}{r}6 \\
10\end{array}$ & $\begin{array}{l}55 \pm 15 \\
90 \pm 13\end{array}$ \\
\hline
\end{tabular}

The most significant factor influencing survival appeared to be the continuation of artificial ventilation and the maintenance of an airway during the postischaemic period. If the return of reflexes was judged on clinical grounds to be adequate for the protection of the airway (i.e., vigorous chewing, active mobility of the tongue, vigorous coughing), the animal was extubated; the extubation time correlated well with the prognosis (Table VIII). Following a three-minute

TABLE VIII

Extubation after 3 Minutes of Cerebrac Ischaemia-Comparison getween Survivors and Fatalities

\begin{tabular}{lccccc}
\hline \hline \multirow{2}{*}{$\begin{array}{l}\text { Extubation after } \\
\text { cerebral ischaemia }\end{array}$} & \multicolumn{2}{c}{ Survivors (28) } & & \multicolumn{2}{c}{ Fatalities (19) } \\
\cline { 2 - 3 } \cline { 5 - 6 } \cline { 5 - 6 } & $\mathrm{N}_{2} \mathrm{O}$ & $\mathrm{N}_{2} \mathrm{O}+$ halothane & & $\mathrm{N}_{2} \mathrm{O}$ & $\mathrm{N}_{2} \mathrm{O}+$ halothane \\
\hline During 1st hour & 8 & 15 & & 0 & 0 \\
During 2nd hour & $\mathbf{2}$ & 3 & & 5 & 1 \\
Over 2 hours & 0 & 0 & & 6 & 0 \\
Died before extubation & 0 & 0 & 7 & 0 \\
\hline
\end{tabular}

ischaemia, 23 of 28 survivors could be extubated during the first hour, the remainder during the second hour. Of the 19 fatalities only six could be extubated during the second hour, six required intubation for longer than two hours and seven died prior to extubation. With longer periods of occlusion, the return of spontaneous respiratory activity was further delayed; it was also found that during the early part of the recovery of respiratory activity, the spontaneous ventilation was inadequate to maintain oxygenation. In order to afford survival these animals had to be ventilated for one to two hours or more, often long past the point of return of spontaneous respiration, and the endotracheal tube was deliberately left in place for many hours. With this type of management, the extubation time was no longer in functional relationship to the recovery of the brain.

\section{Discussion}

The technique of producing cerebral ischaemia in rabbits by the application of a tourniquet around the neck has been extensively studied by German investi- 
gators and was considered reliable. It was recently criticized by Wright ${ }^{\bullet}$ who failed to obtain satisfactory occlusion but used only $300 \mathrm{~mm}$. Hg inflation pressure for the tourniquet. In a classical paper, Cushing noted that the blood pressure will always rise slightly above the intracranial pressure; it can reach increases up to 200 per cent in an attempt to maintain cerebral circulation. ${ }^{10}$ With occlusion pressures of 700 to $800 \mathrm{~mm}$. Hg we have been able to maintain an isoelectric E.E.G. throughout the period of occlusion in approximately 90 per cent of all our experiments. Any sign of a returning cortical activity, even after several minutes of a "flat" E.E.G., was considered a sign of an incomplete occlusion of the circulation. All these animals were eliminated from our series. Preliminary studies with radioactive albumin produced good evidence that there was no blood flow into the head under these conditions.

The tolerance of the brain to ischaemia probably slightly exceeds that of the whole body. ${ }^{6}$ The duration of cerebral ischaemia that is compatible with recovery in cats and rabbits ranged from five to eight minutes, ${ }^{\circ}$ although histological changes were found in spite of an apparently complete recovery. ${ }^{4}$ Longer survivals have been reported with different occlusion techniques; particularly the use of an increase in C.S.F. pressure above $400 \mathrm{~mm}$. Hg has been tolerated for a much longer time with apparently complete recovery.11 It should be noted, however, that a very minimal blood flow can postpone the onset of irreversible damage. ${ }^{12}$ Hypothermia is also known to protect the brain, and even slight reduction in brain temperature may increase the tolerance to ischaemia.4,13,14

According to our results six minutes of cerebral ischaemia under nitrous oxide anaesthesia or in the unanaesthetized animal caused a very high mortality; even after only three minutes of ischaemia there was a substantial number of deaths when a weak agent had been used. The addition of potent anaesthetic agents significantly reduced this mortality and thus afforded a certain protection for these durations of ischaemia. For the three minute period only halothane has been examined and it appeared to offer almost 100 per cent protection.

It was at first surprising that an increase of the period of ischaemia to nine minutes and subsequently to ten and twelve minutes did not reduce the survival rate but only increased the severity of neurological damage observed in the surviving animals. However, this relatively high survival rate was largely dependent on effective methods of resuscitation, such as prolonged artificial ventilation and endotracheal intubation; any deviation from this technique would certainly increase the mortality. Even though the brain is irreparably damaged, structures such as the medulla which are required to sustain vital functions may recover after twelve minutes of ischaemia and function adequately.

The high mortality observed during the first 24 hours in lightly anaesthetized or unanaesthetized rabbits subjected to six minutes of cerebral ischaemia is diffcult to explain. Survival was significantly higher after 12 minutes of ischaemia, even though it was invariably associated with irreversible brain damage. It would appear that potent anaesthetic agents, rather than protecting against irreversible cortical damage, influence the mechanism which induces early death in the lightly anaesthetized animals. The observation that about one-third of the fatalities in this lightly anaesthetized group showed a terminal pulmonary oedema 
may be of significance; this symptom was not seen in animals anaesthetized with potent agents which died in the laboratory. Another difference between the two groups was a somewhat delayed and less vigorous autonomic response at the onset of cerebral ischaemia in the animals anaesthetized with potent agents. These phenomena require further study. However, one might speculate that the inhibition of autonomic responses to cerebral anoxia (and the most pronounced of an autonomic response would be a "neurogenic oedema of the lung"15), could be an important reason for this so-called protective effect of anaesthesia.

It has been stated that since the cerebral circulation is largely pressure regulated, the perfusion pressure at the beginning of restoration of circulation would be of importance for the subsequent outcome. Release of the tourniquet usually resulted in a further fall in pressure, which could add a period of inadequate perfusion of several minutes. However, the systolic blood pressure at the time of release of the tourniquet did not seem to affect survival (Table VI), contrary to other reports. ${ }^{16}$ Even the extreme hypotension observed with halothane or methoxyflurane allowed a substantial survival rate. There was an indication that a high oxygen tension at the beginning of the arrest of cerebral circulation had a favourable influence on survival. The survival rate of all animals anaesthetized with a potent agent with nitrous oxide and subjected to nine minutes of ischaemia was 57 per cent (Table IV) compared to 67 per cent in animals anaesthetized with potent agents and oxygen (Table V).

\section{SUMMarY}

General anaesthesia has been reported to increase the tolerance to cerebral ischaemia. In rabbits the technique of inflating a pneumatic tourniquet around the neck was used to produce cerebral ischaemia for periods of three, six, nine, ten, or twelve minutes. A standard anaesthetic technique with nitrous-oxideoxygen and succinylcholine was maintained for at least 45 minutes prior to this occlusion; potent anaesthetic agents (halothane, methoxyflurane, cyclopropane, and ether) were added for comparison, and these agents were also used in oxygen alone. Artificial ventilation through an orotracheal tube was maintained throughout the experiment until the recovery of reflexes and adequate spontaneous respiration. Normothermia was maintained, and $\mathrm{pH}$ and blood gases were kept in normal range. Blood pressure, E.E.G., and E.C.G. were recorded, and the absence of cortical electrical activity throughout the period of occlusion was considered evidence of cerebral ischaemia. The addition of halothane to the standard nitrousoxide-oxygen mixture increased the 24 -hour survival rate following three minutes of cerebral ischaemia from 36 to 95 per cent and following six minutes of cerebral ischaemia the survival rate was increased from 21 per cent to an average of 72 per cent by halothane, methoxyflurane, and cyclopropane. Only one of six unanaesthetized rabbits survived six minutes of ischaemia. Nitrous-oxide-oxygen supplemented by the same inhalation agents produced a survival rate of 57 per cent following nine minutes of ischaemia, and the survival rose to 67 per cent when these agents were used with oxygen alone. Further prolongation of the ischaemic period to ten and twelve minutes did not reduce this survival rate, but 
the neurological defects of 24 hours became increasingly severe. Survival was not influenced by the blood pressure level at the time of tourniquet release but was largely dependent on the duration of effective resuscitation measures such as artificial respiration and prolonged intubation in the post-ischaemic period.

\section{RÉSUMÉ}

On a dit que l'anesthésie générale augmentait la tolérance à l'ischémie cérébrale. Chez des lapins, nous avons employé la technique du tourniquet pneumatique autour du cou pour produire l'ischémie cérébrale pour des périodes variant de trois, six, neuf, dix ou douze minutes. Nous avons pratiqué durant 45 minutes au préalable une technique d'anesthésie ordinaire avec du protoxyde d'azote, de l'oxygène et de la succinylcholine avant l'occlusion de la circulation; pour fin de comparaison, nous avons ajouté des agents anesthésiques puissants (halothane, méthoxyflurane, cyclopropane et éther) ou ces substances étaient données avec de l'oxygène pur. A l'aide d'un tube orotrachéal, nous avons fait de la ventilation artificielle durant toute l'expérience jusqu'au retour des réflexes et d'une respiration spontanée adéquate. Nous avons maintenu la température près de la normale ainsi que le $\mathrm{pH}$ et les gaz du sang. Nous avons enregistré la tension artérielle, l'E.E.G. et l'E.C.G. et nous avons accepté l'absence d'activité électrique corticale durant la période d'occlusion circulatoire comme signe évident d'ischémie cérébrale. L'addition d'halothane au mélange ordinaire de protoxyde d'azote et d'oxygène a augmenté le taux de survie de 24 heures à la suite de trois minutes d'ischémie cérébrale de 36 à 95 pour cent et, à la suite de six minutes d'ischémie cérébrale, le taux d'augmentation de survie est passé de 21 pour cent à environ 72 pour cent par l'halothane, le méthoxyflurane et le cyclopropane. Seulement un des six lapins anesthésiés a survécu à six minutes d'ischémie. L'anesthésie au protoxyde d'azote et oxygène additionnée de la même façon par les agents mentionnés a permis un taux de survie de 57 pour cent à la suite de neuf minutes d'ischémie et le taux de survie s'est élevé à 67 pour cent si ces agents sont donnés avec de l'oxygène pur. Une prolongation additionnelle de la période d'ischémie de dix à douze minutes n'a pas diminué le taux de survie mais les séquelles neurologiques après 24 heures sont devenues de plus en plus graves. La survie n'a pas été influencée par le niveau de la pression sanguine au moment d'enlever le tourniquet mais plutôt par la durée des mesures efficaces de réanimation telles que la respiration artificielle et l'intubation prolongée au cours de la période post-ischémique.

\section{ACKNOWLEDGMENTS}

This study was conducted in the Department of Physiology. The authors express their gratitude to Professor J. A. F. Stevenson for his support and interest. Mr. Bradley Cott provided valuable technical assistance.

This investigation was supported by a grant from the Medical Research Council of Canada. The generous supply of halothane (Fluothane) by Ayerst, McKenna and Harrison and of methoxyflurane (Penthrane) by Abbott Laboratories of Canada, is gratefully acknowledged. 


\section{REFERENCES}

1. Drruva, H. J. Fluothane as an Anaesthetic Adjuvant for Prevention of Hypoxic Brain Damage. J. Exp. Med. Sci. 5: I (1961).

2. Wells, B. A.; Keats, A. S.; \& Cooley, D. A. General Anaesthesia during Temporary Carotid Occlusion. J. Surg. 54: 221 (1963).

3. Gordstenn, A. H.; Werls, A. W.; \& Keats, A. S. Effect of Anesthesia on the Tolerance of Dog Brain to Anoxia. Anesthesiology. 25: 98 (1964).

4. Hmssck, H. \& MUELIER, H. A. Funktionelle u. histologische Veraenderungen des Kaninchengehirns nach kompletter Gehirnischaemie. Pfluegers Archiv. 275: 277 (1962).

5. Cox, J. M. R.; Catron, D. V.; \& Sponner, W. E. The Effects of Halothane on Cerebral Ischemia in Rabbits. Anesthesiology. 26: 242 (1965).

6. HIrsch, H.; EuLER, K. H.; \& Scanemerk, M. Ueber die Erholung und Wiederbelebung des Gehirns nach Ischaemie bei Normothermie. Pfluegers Archiv. 265: 281 (1957).

7. Stiswart, G. N.; GunTrRme, C. C.; Burns, R. L.; \& PIIE, F. H. The Resuscitation of the Central Nervous System of Mammals. J. Exp. Med. 8: 289 (1906).

8. OprTz, E. \& LoRENzEN, U. K. Vergleich der Wirkungsgeschwindigkeit von reiner Anoxie u. totaler Ischaemie auf das Kaninchengehirn. Pfuegers Archiv. 253: 412 (1951).

9. Wrucrr, R. L. Experimental Cerebral Ischemia. J. Angiol. 16: 397 (1965).

10. Cusming, H. Concerning a Definite Regulatory Mechanism of the Vasomotor Centre which Controls Blood Pressure during Cerebral Compression. Johns Hopkins Hosp. Bull. 12: 290 (1901).

11. Youmans, J. \& NEELY, W. Sequelae of Acute Increase in Intracranial Pressure. J. Trauma. 3: 386 (1963).

12. Hirsch, H.; Koch, D.; Krenkes, W.; \& Schnemen, N. Die Erholungslatenz des Warmbluetergehims bei Ischaemie und die Bedeutung eines Restkreislaufes. Pfluegers Archiv. 261: 392 (1855).

13. Boy, R. J. Tolerance of Anoxia of Dog's Brain at Various Temperatures. Surg. Forum. 12: 408 (1961).

14. Hirsch, H.; Boute, A.; Schandig, A.; \& Toznnis, D. Ueber die Wiederbelebung des Gehirns bei Hypothermie. PAluegers Archiv. 265: 328 (1957).

15. Biscrop, W. Zur Entstehung des Neurogen ausgeloesten akuten Lungenoedems. Berlin, Heidelberg, New York: Springer (1965).

16. GleichananN, U.; Schlosser, V.; \& Schinemer, R. Versuche zur Verlaengerung der Wiederbelebungszeit nach Asphyxie beim Kaninchen. Thoraxchirurgie. 7: 17 (1959). 